\title{
The Influence of Gestation and Mechanical Ventilation on Serum Clara Cell Secretory Protein (CC10) Concentrations in Ventilated and Nonventilated Newborn Infants
}

\author{
ALISON LOUGHRAN-FOWLDS, JULEE OEI, HE WANG, HONGXIU XU, NEIL WIMALASUNDERA, CLAIRE EGAN, \\ RICHARD HENRY, AND KEI LUI
}

Department of Newborn Care [A.L.-F., J.O., N.W., C.E., K.L.], Leslie Stevens Newborn Research Laboratory [L.X., K.L.], Royal Hospital for Women, Randwick, NSW 2031 Australia; School of Women's and Children's Health [J.O., H.W., L.X., R.H., K.L.], University of New South Wales, Randwick, NSW 2031, Australia

\begin{abstract}
Clara cell secretory protein (CC10) is an important anti-inflammatory mediator in the adult lung, but its role in newborn pulmonary protection is uncertain. We examined the early postnatal behavior of $\mathrm{CC} 10$ in newborn serum and tracheal fluid and hypothesized that $\mathrm{CC} 10$ production is positively influenced by gestation. Blood from 165 infants from the first, third/fourth, and seventh days of life (gestational ages: 23-29 wk, 30-36 wk, >36 wk) and tracheal fluid (TF) from the first day of life from 32 ventilated infants were analyzed for CC10. Surfactant proteins A (SPA) and B (SPB) were also analyzed from the blood of a subgroup of infants. Serum CC10 on day 1 was highest in term infants $(69.4 \mathrm{ng} / \mathrm{mL})$, followed by moderately preterm $(55.8 \mathrm{ng} / \mathrm{mL})$, and then extremely preterm infants (median $42.1 \mathrm{ng} / \mathrm{mL}$ ). Term infants also had higher tracheal fluid CC10 than preterm infants. (20.152 ng/mL versus $882 \mathrm{ng} / \mathrm{mL})$. Mechanical ventilation increased serum CC10 only in moderately preterm infants, and only on d $1[68.4 \mathrm{ng} / \mathrm{mL}$ versus $42.1 \mathrm{ng} / \mathrm{mL}$ (nonventilated moderately preterm infants)]. Serum CC10 decreased progressively by the end of the first week in all infants, in contrast to SPA and SPB, which increased. Our results show that CC10 is detectable in the blood of newborn infants and that a production surge occurs at birth. This surge is more pronounced in term infants and may confer them with superior extrauterine pulmonary protection compared with preterm infants. (Pediatr Res 60: 103-108, 2006)
\end{abstract}

$\mathrm{T}$ here has been little impact on the severity and incidence of chronic lung disease (CLD) despite considerable advances in perinatal care (1). The etiology of CLD, a syndrome of persistent respiratory insufficiency in which preterm infants continue to require supplemental oxygen and/or mechanical ventilatory support beyond the postconceptional age of $36 \mathrm{wk}$ (2), remains uncertain, but there is increasing evidence to suggest that premature infants are unable to temper the inflammatory response caused by extrauterine insults such as mechanical ventilation, sepsis, and oxygen (3). An early increase of cellular and humoral inflammatory mediators $(4,5)$,

Received August 2, 2005; accepted February 9, 2006.

Correspondence: Julee Oei, M.B.B.S., FRACP, Department of Newborn Care, Royal Hospital for Women, Barker Street, Randwick, NSW 2031, Australia; e-mail: oeij@sesahs.nsw.gov.au.

This study was supported by grants from the Leslie Stevens Fund for Newborn Care, Sydney Children's Hospital Foundation, and the Roth Foundation, Sydney, Australia.

DOI: $10.1203 / 01 . p d r .0000219388 .56608 .77$ as well as a concomitant decrease in protective antiprotease, antioxidant, surfactant, and anti-inflammatory systems (6), has been noted soon after birth in lung fluids of infants who subsequently developed CLD.

Recently, the 16-kD lung-specific anti-inflammatory protein, CC10 (known as CCSP, uteroglobin, or CC16), produced by nonciliated bronchiolar lung Clara cells, was shown to play a pivotal role in the prevention and amelioration of lung injury in adult mice and humans (7-9). Its effects on the newborn lung, however, are uncertain. The amniotic fluid and TF concentrations of CC10 increase with advancing gestational age $(10-12)$, but whether this is a true representation of a gestational effect on CC10 production is questionable. For example, amniotic fluid studies, although involving large numbers of pregnancies, are predominantly composed of subjects with problematic and genetically abnormal pregnancies $(10,11)$. Lung fluid studies, on the other hand, are usually small (12) and include only ventilated infants. The CC10 profile of normal infants is therefore not easily examined by either of these studies. Fortunately, CC10 is detectable in serum because it leaks passively from the lungs into the circulation through the bronchoalveolar blood barrier (13), and serum CC10 may therefore be used as a surrogate representative of lung CC10.

Serum CC10 has not been comprehensively studied in the neonatal population. There are also currently no data on gestational influence on serum $\mathrm{CC} 10$, and in this study, we sought to examine whether 1) CC10 was detectable in neonatal blood, 2) gestation and pulmonary outcome influences CC10 concentrations, and 3) there was any relationship between $\mathrm{CC} 10$ and the behavior of other pneumoproteins such as SPA and SPB.

We hypothesize that early production of CC10 during extrauterine adaptation is influenced by gestation. Additionally, our secondary hypothesis is that full-term infants will have

Abbreviations CC10, Clara cell secretory protein, CLD, chronic lung disease, RDS, respiratory distress syndrome, SP, surfactant protein, TF, tracheal fluid, TTN, transient tachypnea of the newborn 
higher concentrations of CC10 in both serum and TFs than premature infants at high risk of developing CLD.

\section{METHODS}

The infants in this study were recruited from the neonatal intensive care unit at the Royal Hospital for Women in Randwick, Australia, between June 2001 and December 2003. Infants were eligible for the study if they were less than $24 \mathrm{~h}$ of age at time of enrollment and if they required blood tests as part of routine medical management. Infants with major chromosomal anomalies, congenital anomalies of the lungs, or pulmonary hypoplasia were excluded. The infants were divided into three gestational cohorts consisting of extremely premature infants (23-29 wk gestation), moderately premature infants (30-36 wk gestation), and term infants ( $>36$ wk gestation).

We obtained $0.5 \mathrm{~mL}$ of blood (by venous, arterial, or heel puncture) from each infant on d 1,3-4, and 7 of life. Blood sampling was timed to coincide with medically indicated blood tests. D 7 specimens were not collected in term infants because most had been discharged from hospital by that time. Investigations were extended to include SPA and SPB assays during a later part of the study, in which an extra $0.2 \mathrm{~mL}$ of blood was obtained from consecutively enrolled infants for SPA and SPB measurement. TFs were collected from mechanically ventilated infants on the first day during routine pulmonary toilet: $0.5 \mathrm{~mL}$ of saline was instilled in the endotracheal tube and the residue suctioned after two to three ventilator breaths (6).

All specimens were immediately spun in an on-site laboratory for $10 \mathrm{~min}$ at 3500 RPM and the supernatant frozen and stored at $-70^{\circ} \mathrm{C}$ until analysis. CC10 was assayed in serum and TF in batches of 40 in duplicates by a commercially available CC10 enzyme-linked immunosorbent assay (ELISA) (DIAMED, Belgium) (14). This uses anti-monoclonal antibody for quantitative determination of $\mathrm{CC} 10 . \mathrm{CC} 10$ is then bound to specific biotin-conjugated antibodies, and the amount present is detected by addition of streptavidinhorseradish peroxidase, hydrogen peroxide, and tetramethylbenzidine buffer solution. Absorbency is measured at $450 \mathrm{~nm}$ and standard curves generated to determine CC10 concentrations. Detection limits are $0.03 \mathrm{ng} / \mathrm{mL}$. The intraand interassay coefficients of variation of the method are less than $4 \%$ at a level of $0.1 \mathrm{ng} / \mathrm{mL}$ and less than $3 \%$ at a level of $3 \mathrm{ng} / \mathrm{mL}$ (15). We confirmed in our laboratory that the CCSP standards used in the ELISA kit were of the same molecular weight as the recombinant human $\mathrm{CC} 10$ (rhCC10) (courtesy of April Pilon, Claragen, Baltimore, MD) and verified by Western blot that the ELISA kit antibodies recognized rhCC10.

CC10 assay values were expressed as weight per volume lavage fluid because an acceptable method for standardizing solute quantities in pulmonary lavage specimens has not been well established (16).

Serum SPA and SPB were measured in duplicate at four serial dilutions with ELISA inhibition assays by Flinders University, Adelaide, using previously established methods (17). Briefly SPA and SPB were first freed from any associated components using ethylenediaminetetraacetic acid, sodium dodecylsulfate, and Triton X-100. The proteins were then measured with ELISA inhibition assays using polyclonal antibodies raised against alveolar proteinosis-derived SPA and mature SPB, respectively. Absorbance was measured at $405 \mathrm{~nm}$, and standard curves were generated to compute the concentration in each sample.

Demographic details recorded included antenatal steroids, maternal cigarette exposure, pregnancy and delivery histories, resuscitation, and ventilatory parameters.

Respiratory disease was diagnosed clinically and radiologically and included respiratory distress syndrome (RDS), transient tachypnea of the newborn (TTN), and other respiratory disorders. Infants with respiratory disease were treated according to nursery protocol, which included mechanical ventilation and oxygen for most extremely premature infants and continuous positive airway pressure for less premature infants with mild disease. Survanta ${ }^{\circledR}$, which contains SPB but not SPA, was used in treatment of radiologically diagnosed RDS. Neonatal outcomes examined included mortality and the development of CLD, which was defined as the need for supplemental oxygen and/or ventilatory support at and beyond the postconceptional age of $36 \mathrm{wk}$ in premature infants (2). No infant received steroids during the period of sample collection.

Variance of serum CC10 concentrations, obtained from a pilot sample of 28-32 wk gestation infants, was used for sample size calculations. This showed that 19 infants were required in each group to demonstrate adequate differences (to test for a mean difference of $5 \mathrm{ng} / \mathrm{mL}$, alpha $=0.01$, power $=$ 0.90 , two-tailed test). Categorical data were analyzed by Fisher's exact test and/or $\chi^{2}$ test. Nonparametric analyses were used (Mann-Whitney $U$, Kruskal-Wallis, Friedman, Spearman's rho, and Wilcoxon). A $p<0.05$ was considered significant. No infants were excluded from overall analyses but were excluded from CLD analysis if they died before 36 wk gestational age.
The Institutional Ethics Committee of the South East Sydney Area Health Service approved the study and signed informed consent was obtained from each infant's parents.

\section{RESULTS}

Blood samples $(N=312)$ were collected from 165 infants. Sixty were extremely premature (23-29 wk gestation; median $27 \mathrm{wk}), 66$ were moderately premature $(30-36 \mathrm{wk}$ gestation; median $33 \mathrm{wk}$ ), and 39 were full term (median $40 \mathrm{wk}$ ); demographic characteristics are summarized in Table 1. Only six term infants remained in the nursery by the end of the first week of life and therefore, $\mathrm{d} 7$ blood results from this group were not included in our analysis. Investigations were extended in a later part of the study to include collection of an extra $0.2 \mathrm{~mL}$ of blood from a consecutive subpopulation of 41 infants (14 extremely preterm, 19 moderately preterm, and eight term) for serum SPA (97 samples) and SPB (95 samples) measurement. There was no difference in the demographics of the two groups.

Relationship between gestation, postnatal age, and serum CC10. The first collection of blood occurred at a median of $12 \mathrm{~h}$ (interquartile range: $3-19 \mathrm{~h}$ ] after birth for all groups. D 1 CC10 concentrations were significantly influenced by gestation, being lowest in extremely preterm infants [median 42.1 $\mathrm{ng} / \mathrm{mL}(17.2,57.8)]$, followed by moderately preterm infants $[55.8 \mathrm{ng} / \mathrm{mL}(26.0,73.9)]$, and highest in term infants [69.4 $\mathrm{ng} / \mathrm{mL}(59.6,73.8) ; p=0.005]$. Subsequent serum CC10 concentrations stayed relatively stable in extremely preterm infants [d 4: $32.7 \mathrm{ng} / \mathrm{mL}(15.7,51.6) ; \mathrm{d}$ 7: $26.8 \mathrm{ng} / \mathrm{mL}$ (17.5, 44.6); $p=0.738]$ but fell significantly in the other two groups in comparison with d 1 [moderately preterm d 4: $31.2 \mathrm{ng} / \mathrm{mL}$ $(19.0,61.4) ; \mathrm{d} 7: 28.9 \mathrm{ng} / \mathrm{mL}(14.7,56.2), p=0.004$; term d 4: $25.2 \mathrm{ng} / \mathrm{mL}(15.4,55.8) ; \mathrm{d} 7: 23.9 \mathrm{ng} / \mathrm{mL}$ (13.71, 34.0), $p=$ 0.006] (Fig. 1).

Relationship between gestation and TF CC10. Of the 165 infants, 89 were ventilated and therefore eligible for TF collection. This was limited to office hours because of laboratory staff availability (samples had to be spun within an hour of collection). TF was collected from 49 infants on $\mathrm{d} 1$, but 17 were rejected for testing because of an unsuitably small volume of return (less than $100 \mu \mathrm{L}$ ) (6). TFs were analyzed in 32 infants: 18 extremely premature, five moderately premature, and nine full term. There were no overall demographic biases between sampled infants and nonsampled ventilated infants.

TF CC10 on d 1 correlated positively with gestation (Spearman's rho correlation coefficient $0.410, p<0.020$ ). The median concentration in preterm infants was $882 \mathrm{ng} / \mathrm{mL}(442$, 2655) [compare term infants: $20,152 \mathrm{ng} / \mathrm{mL}(724,43,112), p$ $=0.022]$.

Postnatal behavior of serum SPs. D 1 serum SPA concentrations from the subgroup of 41 infants (Fig. 2) were similar to those of serum CC10. Extremely preterm infants had lowest concentrations $[0.7 \mu \mathrm{g} / \mathrm{mL}(0.6,2.3)]$ followed by moderately preterm infants $[1.0 \mu \mathrm{g} / \mathrm{mL}(0.6,1.3)]$ and then term infants $[1.1 \mu \mathrm{g} / \mathrm{mL}(0.67,1.6), p=0.958]$. However, SPA concentrations rose on $\mathrm{d} 4$ in all gestations, and this increase was most pronounced in more mature infants $[0.8 \mu \mathrm{g} / \mathrm{mL}(0.6$, 
Table 1. Demographic characteristics

\begin{tabular}{|c|c|c|c|c|}
\hline Gestational group & $23-29 w k$ & $30-36 \mathrm{wk}$ & Full term & $p$ \\
\hline No. of infants & 60 & 66 & 39 & \\
\hline Gestation (wk) & $27(25,28)$ & $33(31,34)$ & $40(38,40)$ & $<0.001$ \\
\hline \multicolumn{5}{|l|}{ Antenatal variables } \\
\hline Antenatal steroids & $53(88 \%)$ & $31(47 \%)$ & $0(0 \%)$ & $<0.001$ \\
\hline $\mathrm{PIH} / \mathrm{PET}$ & $8(13 \%)$ & $16(24 \%)$ & $2(5 \%)$ & 0.028 \\
\hline Chorioamnionitis & $19(32 \%)$ & $8(12 \%)$ & $0(0 \%)$ & $<0.001$ \\
\hline PROM & $16(27 \%)$ & $15(23 \%)$ & $2(5 \%)$ & 0.025 \\
\hline \multicolumn{5}{|l|}{ Birth variables } \\
\hline Birth weight (g) & $1010(780,1252)$ & $1942(1658,2333)$ & $3357(2966,3708)$ & $<0.001$ \\
\hline Sex (male) & $37(62 \%)$ & $33(50 \%)$ & $22(56 \%)$ & 0.406 \\
\hline Delivery (vaginal) & $28(47 \%)$ & $16(24 \%)$ & $25(64 \%)$ & 0.001 \\
\hline Apgar score, $1 \mathrm{~min}$ & $6(4,8)$ & $8(7,9)$ & $8(4,9)$ & 0.001 \\
\hline Apgar score, $5 \mathrm{~min}$ & $8(6,9)$ & $9(8,9)$ & $9(7,9)$ & 0.010 \\
\hline \multicolumn{5}{|l|}{ Respiratory diseases } \\
\hline RDS & $48(80 \%)$ & $22(33 \%)$ & $1(3 \%)$ & $<0.001$ \\
\hline TTN & $8(13 \%)$ & $13(20 \%)$ & $11(28 \%)$ & \\
\hline Meconium aspiration syndrome & & & $6(15 \%)$ & \\
\hline Pneumothorax & & & $2(5 \%)$ & \\
\hline PPHN & & $1(2 \%)$ & $2(5 \%)$ & \\
\hline Others & $2(4 \%)$ (hydrops, apnea) & & $3(8 \%)$ (TOF, apnea) & \\
\hline Hypoxic ischemic encephalopathy & & & $3(8 \%)$ & \\
\hline No respiratory illness, no support & $2(3 \%)$ & $30(45 \%)$ & $11(28 \%)$ & \\
\hline \multicolumn{5}{|l|}{ Respiratory support } \\
\hline Mechanical ventilation \pm CPAP & $49(82 \%)$ & $24(36 \%)$ & $16(41 \%)$ & $<0.001$ \\
\hline CPAP only & $7(12 \%)$ & $5(8 \%)$ & $0(0 \%)$ & \\
\hline Highest $\mathrm{FiO}_{2}$ during first week & $0.80(0.35,1.00)$ & $0.28(0.21,0.45)$ & $0.32(0.21,0.93)$ & $<0.001$ \\
\hline Surfactant treatment & $42(70 \%)$ & $15(23 \%)$ & $3(8 \%)$ & $<0.001$ \\
\hline HFOV therapy & $10(17 \%)$ & $0(1 \%)$ & $3(8 \%)$ & 0.002 \\
\hline Nitric oxide therapy & $9(15 \%)$ & $1(2 \%)$ & $3(8 \%)$ & 0.018 \\
\hline Patent ductus arteriosus & $19(32 \%)$ & $6(9 \%)$ & $3(8 \%)$ & 0.001 \\
\hline \multicolumn{5}{|l|}{ Outcomes } \\
\hline CLD & $14(23 \%)$ & $1(2 \%)$ & $0(0 \%)$ & $<0.001$ \\
\hline Death & $15(25 \%)$ & $0(0 \%)$ & $0(0 \%)$ & $<0.001$ \\
\hline
\end{tabular}

Median (first, third quartiles) and number of infants (\%) are shown.

PIH/PET, pregnancy-induced hypertension/preeclamptic toxemia; GBS, group B streptococcus; PROM, prolonged rupture of membranes; PPHN, persistent pulmonary hypertension of the newborn; TOF, tracheal esophageal fistula; CPAP, continuous positive airway pressure; $\mathrm{FiO}_{2}$, fraction inspired oxygen; $\mathrm{HFOV}$, high-frequency ventilation.

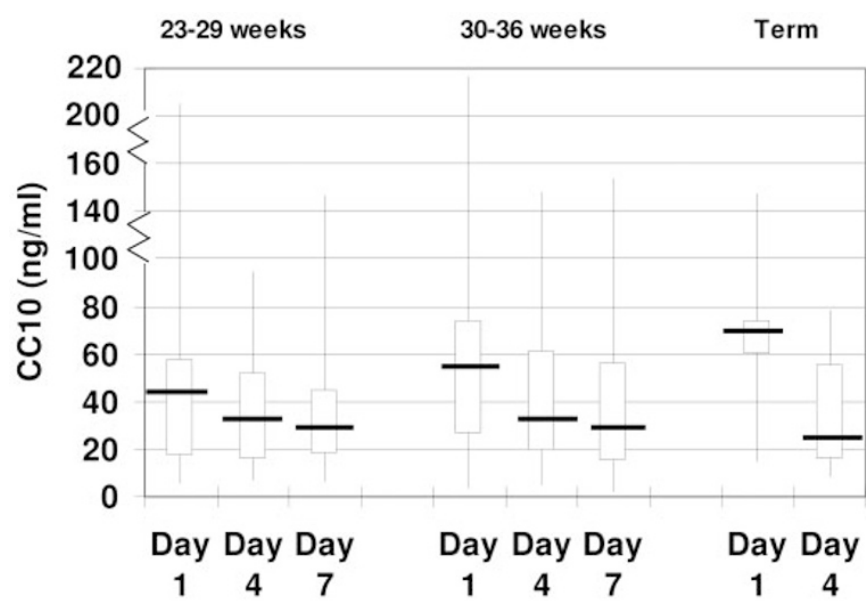

Figure 1. Relationship of $\mathrm{CC} 10$ to postnatal age: d 1, 4, and 7 serum concentrations. Median (bars), quartiles (boxes), and ranges (vertical lines) are shown. Extremely preterm number of infants $(n=60, p=0.738)$; moderately preterm $(n=66, p=0.004)$; term $(n=39, p=0.006)$.

1.4), $1.3 \mu \mathrm{g} / \mathrm{mL}(0.9,1.9)$, and $1.9 \mu \mathrm{g} / \mathrm{mL}(1.6,2.4)$, respectively; $p=0.008]$.

Ten (24\%) of the 41 infants had RDS, and all received surfactant treatment before collection of the $\mathrm{d} 1$ samples.

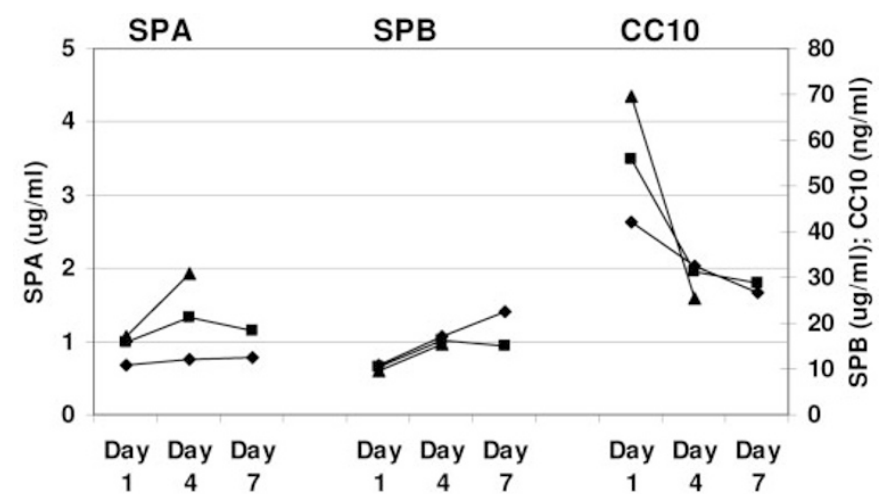

Figure 2. Postnatal pattern of serum pneumoproteins: Median concentrations of $\mathrm{d} 1,4$, and 7 are shown. $\bullet$, term infants; $\mathbf{\square}$, moderately preterm infants; $\boldsymbol{\Delta}$, extremely preterm infants.

Serum SPB varied more greatly than SPA, but no observable differences were seen in serum SPB between the gestational groups: extremely preterm: $10.7 \mu \mathrm{g} / \mathrm{mL}(6.9,18.3)$, moderately preterm: $10.2 \mu \mathrm{g} / \mathrm{mL}(6.5,16.8)$, and term: $9.5 \mu \mathrm{g} / \mathrm{mL}$ $(3.1,14.5)(p=0.757)$. Serum SPB increased by almost twofold on $\mathrm{d} 4$, but there was no apparent gestational influence (Fig. 2): $21.8 \mu \mathrm{g} / \mathrm{mL}$ (13.2, 33.5), $16.1 \mu \mathrm{g} / \mathrm{mL}$ (13.6, 22.9), and $15.3 \mu \mathrm{g} / \mathrm{mL}(10.7,23.0)$, respectively $(p=0.919)$. 
Influence of ventilation and RDS on serum CC10 in corresponding gestation groups. Only four extremely premature infants did not require ventilatory support, $80 \%$ had RDS, and all but one were treated with Survanta ${ }^{\circledR}$. Infants treated with Survanta ${ }^{\circledR}$ did not have statistically different concentrations of $\mathrm{CC} 10$ compared with those untreated [extremely preterms: d 1: $44.8 \mathrm{ng} / \mathrm{mL}(15.0,63.2)$ versus $30.2 \mathrm{ng} / \mathrm{mL}$ (21.2, 55.2), $p=0.742 ; \mathrm{d} 4: 24.2 \mathrm{ng} / \mathrm{mL}(15.6,52.6)$ versus $37.6 \mathrm{ng} / \mathrm{mL}$ (28.6, 48.3), $p=0.519$; moderately preterm: $\mathrm{d} 1$ : $55.4 \mathrm{ng} / \mathrm{mL}(43.3,71.6)$ versus $55.2 \mathrm{ng} / \mathrm{mL}(24.7,73.9), p=$ $0.739 ; \mathrm{d} 4: 31.5 \mathrm{ng} / \mathrm{mL}(14.2,38.3)$ versus $34.5 \mathrm{ng} / \mathrm{mL}$ (19.6, $65.4), p=0.297)$.Ventilated infants had slightly higher $\mathrm{d} 1$ serum CC10 than nonventilated infants $[44.9 \mathrm{ng} / \mathrm{mL}(18.4$, $60.5)$ versus $24.2 \mathrm{ng} / \mathrm{mL}(18.3,27.2) ; p=0.257]$. Concentrations were also slightly higher in the 48 infants with RDS compared with infants without RDS on d $1[49.3 \mathrm{ng} / \mathrm{mL}$ (16.0, 69.8) versus $12 \mathrm{non}-\mathrm{RDS} 24.0 \mathrm{ng} / \mathrm{mL}(20.8,30.2), p=0.307]$, but concentrations on $\mathrm{d} 4$ and 7 were not different between the groups.

These differences were most marked in moderately preterm infants, in whom ventilation was associated with considerably higher d 1 CC10 concentrations [24 ventilated: $66.1 \mathrm{ng} / \mathrm{mL}$ (50.9, 78.5) versus 32 nonventilated: $41.8 \mathrm{ng} / \mathrm{mL}(23.9,71.2)$; $p=0.013$ ] (Fig. 3). Moderately preterm infants with RDS, however, had CC10 concentrations similar to those without RDS on d 1 of life [22 RDS infants: $55.4 \mathrm{ng} / \mathrm{mL}(43.1,71.8)$ versus 44 non-RDS infants: $56.2 \mathrm{ng} / \mathrm{mL}(25.0,74.7), p=$ $0.173]$.

There was no difference in CC10 concentrations between ventilated and nonventilated term infants [ventilated: 70.8 $\mathrm{ng} / \mathrm{mL}(58.6,82.4)$ versus nonventilated: $69.4 \mathrm{ng} / \mathrm{mL}(59.6$, 73.8); $p=0.682]$. The influence of RDS in this group was not analyzed because only one infant had RDS.

Maternal antenatal steroid treatment was examined as a confounder and was found to be an insignificant first day influence on preterm serum CC10 [extremely preterm maternal steroid: $42.1 \mathrm{ng} / \mathrm{mL}(15.7,57.7)$ versus no maternal steroid: $55.7 \mathrm{ng} / \mathrm{mL}(24.0,116.0), n=53(88 \%): p=0.266$; moderately preterm $56.9 \mathrm{ng} / \mathrm{mL}(39.5,72.4)$ versus 55.5 $\mathrm{ng} / \mathrm{mL}(24.7,74.4), n=31$ (47\%): $p=0.876]$.

Smoking history was obtained for mothers of 132 infants. Smoking did not influence serum CC10 on any days [E.G. d 1:

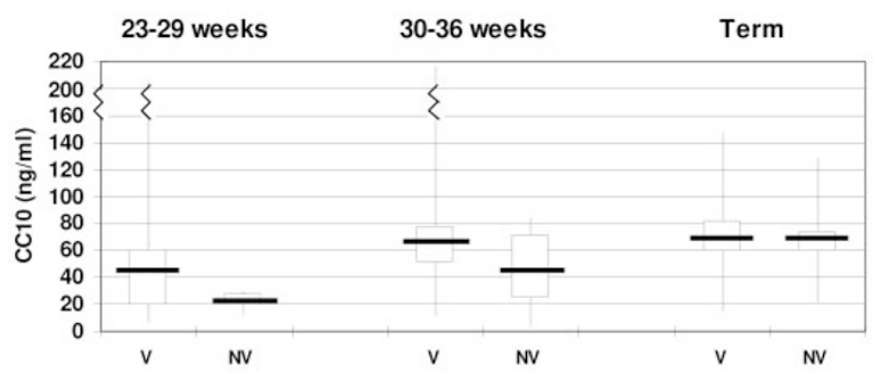

Figure 3. Influence of ventilation on serum pneumoproteins: $d 1$ concentrations of three gestational groups. Median (bars), quartiles (boxes), and ranges (vertical lines) are shown. $\mathrm{V}$, ventilated; $\mathrm{NV}$, nonventilated; 56 ventilated extremely preterm infants, four nonventilated extremely preterm infants, $p=$ $0.257 ; 29$ ventilated moderately preterm infants, 37 nonventilated moderately preterm infants, $p=0.013 ; 16$ ventilated term infants, 23 nonventilated term infants, $p=0.682$ extremely preterm exposed: $55.2 \mathrm{ng} / \mathrm{mL}(22.0,66.5)$ versus not exposed: $34.9 \mathrm{ng} / \mathrm{mL}(14.9,56.2), n=11(22 \%), p=$ 0.634 ; moderately preterm exposed: $74.7 \mathrm{ng} / \mathrm{mL}(61.6,77.3)$ versus not exposed: $57.3 \mathrm{ng} / \mathrm{mL}(36.5,78.8), n=7(11 \%), p$ $=0.278$; term exposed: $88.7 \mathrm{ng} / \mathrm{mL}(59.4,118.1)$ versus not exposed: $69.3 \mathrm{ng} / \mathrm{mL}(57.9,76.0), n=4(10 \%), p=0.766]$.

Relationship between serum CC10 and CLD. Only one (2\%) moderately preterm infant developed CLD. Fifteen (25\%) of the 23-29 wk infants died, two from respiratory failure and one from pulmonary hemorrhage. Most deaths were from nonrespiratory causes, including intraventricular hemorrhages $(n=7)$, necrotizing enterocolitis $(n=2)$, meconium peritonitis $(n=1)$, hypotension $(n=1)$, and sepsis $(n=$ 1). All the deaths occurred before $36 \mathrm{wk}$ postconceptional age, and hence infants were excluded from analyses involving CLD. Fourteen (23\%) infants developed CLD. All CLD infants and 19 of the 31 non-CLD infants were ventilated. Serum CC10 was slightly, but not significantly, lower on d 1 and 4 in CLD infants [d 1: $15.0 \mathrm{ng} / \mathrm{mL}(11.6,72.4)$ versus 37.7 $\mathrm{ng} / \mathrm{mL}(21.5,56.2), p=0.500 ; \mathrm{d} 4: 21.6 \mathrm{ng} / \mathrm{mL}(15.2,31.0)$ versus $33.8 \mathrm{ng} / \mathrm{mL}$ (22.5, 48.3), $p=0.201]$ (Fig. 4).). A stronger trend was obtained if respiratory deaths were included in the analysis of CLD [d 1: $14.7 \mathrm{ng} / \mathrm{mL}(11.0,72.2)$ versus $49.4 \mathrm{ng} / \mathrm{mL}(24.1,57.8), p=0.116 ; \mathrm{d} 4: 20.4 \mathrm{ng} / \mathrm{mL}$ $(14.1,29.0)$ versus $37.4 \mathrm{ng} / \mathrm{mL}(22.7,57.2), p=0.068]$.

Relationship between serum pneumoproteins and renal function. Serum CC10, SPA, and SPB were analyzed in conjunction with serum creatinine to determine the effects of renal function. All proteins showed no significance on d 1, 4, and 7 when compared with serum creatinine.

\section{DISCUSSION}

To our knowledge, this is the first study to comprehensively demonstrate the behavior of serum CC10 in newborn infants during the first week of life. Apart from a small renal contribution, the majority of CC10 originates from the lungs (18), and one can assume that the CC10 that we analyzed from blood was a result of passive diffusion from the lungs to the circulation. Only minute amounts of CC10 cDNA have been found in human placentas and uteruses (19); therefore, it is unlikely that maternal contribution would be significant. Our

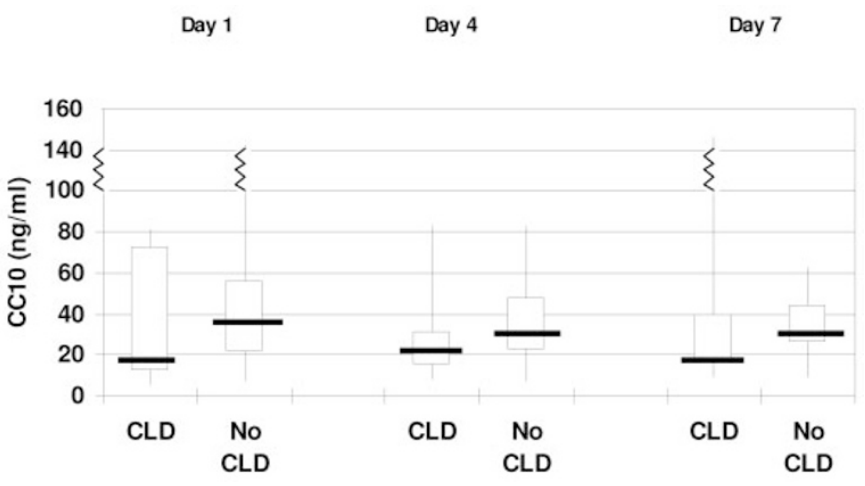

Figure 4. Relationship between serum pneumoproteins and CLD. D 1, 4, and 7 concentrations of extremely premature infants. Median (bars), quartiles (boxes), and ranges (vertical lines) are shown. Fourteen CLD infants; 46 infants with no CLD. D $1 p=0.500, \mathrm{~d} 4 p=0.201, \mathrm{~d} 7 p=0.259$. 
results suggest that extremely preterm infants, especially those prone to CLD, produce less pulmonary $\mathrm{CC} 10$ than more mature infants with a good pulmonary outcome.

Differences in CC10 production may be vital in postnatal extrauterine pulmonary adaptation and in the development of the type of lung injury frequently associated with lung immaturity. CC10 is anti-inflammatory and inhibits phospholipase $\mathrm{A}_{2}\left(\mathrm{PLA}_{2}\right)$ activity (7), the production and function of interferon- $\gamma(9)$, and the chemotaxis of fetal lung fibroblasts (7). The importance of $\mathrm{CC} 10$ in preventing lung injury has been demonstrated in genetically modified CC10-deficient mice, which have an increased sensitivity and exaggerated inflammatory response to lipopolysaccharide and hyperoxic or ozone-induced lung injury (20).

All the newborn infants in our study, regardless of lung disease, had much higher concentrations of serum CC10 than healthy adults $(9-21 \mathrm{ng} / \mathrm{mL})(21)$. Such concentrations may be necessary for acute postnatal lung adaptation. However, excessively elevated concentrations may also be an indication of a disrupted or underdeveloped bronchoalveolar blood barrier. For example, adults and animals with inflammatory lung disease and damaged pulmonary barriers have increased leakage of $\mathrm{CC} 10$ from the lungs into the circulation, as indicated by decreased pulmonary effluent and increased serum concentrations of CC10 (22). In our study, higher concentrations of serum $\mathrm{CC} 10$ in ventilated preterm infants may have been due to be a disruption of the bronchoalveolar blood barrier, either from lung disease or mechanical ventilation or from an underdeveloped barrier in extremely premature infants, but our TF studies confirmed that $\mathrm{CC} 10$ concentrations were, indeed, higher with increasing maturity.

We found that the postnatal behavior of serum CC10 was different from that demonstrated by the SPs; the latter increased toward the end of the first week instead of decreasing. The difference in behavior was not due to selection bias because a comparison of demographics showed no significant differences. This difference also cannot be solely explained by leakage because SPB is of a molecular size similar to that of CC10. The half-life of all three proteins in the circulation is less than $18 \mathrm{~min}$ (23), therefore discounting this as a factor.

The lack of gestational influence on serum SPA was an unexpected finding because fetal lung SPA has been shown to increase with advancing gestation (24). The molecular weight of SPA ( $35 \mathrm{kD})$ is considerably larger than that of CC10, and SPA may therefore be more confined to the intravascular space and not as dependent on glomerular filtration for clearance (23). However, we may have documented a difference in the behavior of serum SPA had we had obtained blood from more infants.

A gestational influence on $\mathrm{CC} 10$ production has been suggested by previous studies on amniotic fluid and TF of mechanically ventilated premature infants $(10-12)$. CC10 is detectable in amniotic fluid from 15 wk of gestation (10) and increases with advancing gestation, possibly due to fetal airway growth $(10,11)$. In a cross-sectional study of ventilated premature infants during the first $2 \mathrm{wk}$ of life (median gestation 27.9 wk), CC10 concentrations in TF increased with both postnatal age and gestation (12). None of these studies, how- ever, explored early postnatal changes. We studied infants from a wider gestational range and our longitudinal analysis included both nonventilated and healthy infants. Our results showed that term infants who are better equipped for extrauterine life had highest serum and TF CC10 on d 1; these new findings indicate that $\mathrm{CC} 10$ production at birth may be an important part of postnatal adaptation.

The influence of mechanical ventilation on serum $\mathrm{CC} 10$ concentration in premature infants is more difficult to delineate as this parameter is confounded by the two most important influences on serum $\mathrm{CC} 10$ concentrations: gestation and RDS. These two factors are inversely interdependent and in the extremely premature group, very few infants escaped mechanical ventilation and the majority had RDS. A small number had TTN and other disorders and were separated from the RDS group for analysis. In the moderately premature group, however, RDS did not make a difference to serum CC10 concentrations, even though a difference was seen between the ventilated and nonventilated infants. These results imply that CC10 production is independent of the surfactant system, as suggested by previous studies (11).

Elevated serum CC10 in ventilated preterm infants may have been caused by leakage through a damaged fragile preterm bronchoalveolar barrier. A proinflammatory response may have been incited by damage caused by mechanical ventilation, but this type of response usually takes a few days to weeks (25) and is not usually evident on the first day of life, as seen in the CC10 changes in this study, where serum CC10 continued to fall despite continued ventilation. We may not have found a demonstrably noticeable difference in serum $\mathrm{CC} 10$ between ventilated and unventilated term infants because of the heterogeneous variety of respiratory disease in this group. More studies, particularly in animal models, are required to investigate this.

This study also showed that CLD infants had the lowest serum CC10 concentrations compared with gestationally similar infants. Although infants at risk of developing CLD are usually ventilated, have RDS, and receive surfactant, these factors are not prerequisites for the development of CLD (26). When results for infants who died from respiratory causes were included in the analysis, serum concentrations of CC10 were even lower (although this difference was not significant: $p=0.068$ ). The number of CLD infants in our cohort was small, and further studies with larger sample sizes of CLDprone infants are required to explore the relationship between low levels of CC10 and CLD. This finding has important therapeutic implications as recombinant $\mathrm{CC} 10$ has been shown to confer significant pulmonary protection in newborn infants and animals $(27,28)$.

We expressed CC10 concentrations as weight per volume lavage TF because an acceptable method for standardizing solute quantities in TF specimens is not well established (16). Adjustment for various markers can be performed; however, they have been found to be unreliable for the calculation TF dilution (29). Albumin is especially unsuitable as a denominator as there is little relation between serum and TF concentrations $(29,30)$, the latter being also subject to variation because of acute flux and disease activity (30), particularly in 
the context of heterogeneous lung diseases in our study population. The magnitude of CC10 difference in TF was much higher than anticipated from the serum levels. This may suggest enhanced $\mathrm{CC} 10$ production in full-term infants in response to lung disease.

In conclusion, our study has demonstrated that CC10 is detectable in blood of newborn infants and that production of CC10 is highest on the first day of life. We have also demonstrated that $\mathrm{CC} 10$ production is correlated to gestational age and that the importance of $\mathrm{CC} 10$ as an anti-inflammatory pneumoprotein places those with CC10 deficiency at possible risk of postnatal respiratory injury. CC10 production also appears independent of surfactant maturation, and further studies assessing the role of CC10 in extrauterine adaptation are urgently needed.

Acknowledgments. We thank the parents, newborn babies, and staff of the Department of Newborn Care at the Royal Hospital for Women for participating in this study and in collecting samples; the South Eastern Area Laboratory Services, especially Assisant Professor Daya Naidoo and Dr. Ora Lux, for help with initial sample collation and storage; Drs. Ian Doyle and Heather Barr, Flinders University, Adelaide, for performing surfactant protein assays and Andrew Fowlds for computer support.

\section{REFERENCES}

1. Egberts J, Brand R, Walti H, Bevilacqua G, Breart G, Gardini F 1997 Mortality, severe respiratory distress syndrome and chronic lung disease of the newborn are reduced more after prophylactic than after therapeutic administration of the surfactant Curosurf. Pediatrics 100:e4

2. Shennan AT, Dunn MS, Ohlsson A, Lennox K, Hoskins EM 1988 Abnormal pulmonary outcomes in premature infants: prediction from oxygen requirement in the neonatal period. Pediatrics 82:527-532

3. Jobe A, Bancalari E 2001 Bronchopulmonary dysplasia. Am J Respir Crit Care Med 163:1723-1729

4. Groneck P, Speer CP 1995 Inflammatory mediators and bronchopulmonary dysplasia. Arch Dis Child Fetal Neonatal Ed 73:F1-3

5. Ramsey P, Demayo J, Hegemier S, Wearden ME, Smith CV, Welty SE 2001 Clara cell secretory protein oxidation and expression in premature infants who develop bronchopulmonary dysplasia. Am J Respir Crit Care Med 164:155-161

6. Oei J, Lui K, Wang H, Henry R 2003 Decreased neutrophil apoptosis in tracheal fluids of preterm infants at risk of chronic lung disease. Arch Dis Child Fetal Neonatal Ed 88:F245-F249

7. Lesur O, Bernard A, Arsalane K, Lauwerys R, Begin R, Cantin A, Lane D 1995 Clara cell protein (CC-16) induces a phospholipase A2-mediated inhibition of fibroblast migration in vitro. Am J Respir Crit Care Med 152:290-297

8. Watson TM, Reynolds SD, Mango GW, Boe IM, Lund J, Stripp BR 2001 Altered lung gene expression in CCSP-null mice suggests immunoregulatory roles for Clara cells. Am J Physiol 281:L1523-L1530
9. Dierynck I, Bernard A, Roels H, De Ley M 1995 Potent inhibition of both human interferon-gamma production and biological activity by the Clara cell protein $\mathrm{CC} 16$. Am J Respir Cell Mol Biol 12:205-210

10. Bernard A, Thielemans N, Lauwerys R, Langhendries JP, Van Lierde M Freund MM 1994 Clara cell protein in human amniotic fluid: a potential marker of fetal lung growth. Pediatr Res 36:771-775

11. Maturana A, Bernard A, Germain AM, Chau VL, Moya FR 2001 Amniotic fluid Clara cell protein concentration in normal pregnancy, a marker of fetal airway growth or fetal lung maturation? J Perinatol 21:516-520

12. Lassus P, Nevalainen TJ, Eskola JU, Andersson S 2000 Clara-cell secretory protein in preterm infants' tracheal aspirates correlates with maturity and increases in infection. Pediatr Pulmonol 30:466-469

13. Bernard A, Marchandise F, Depelchin S, Lauwerys R, Sibille Y 1992 Clara cell protein in serum and bronchoalveolar lavage. Eur Respir J 5:1231-1238

14. DiaMed-Eurogen 2004 CC16 ELISA. Enzyme immunoassay for the quantitative determination of Clara cell $16 \mathrm{kDa}$ protein (CC16). Belgium (http://www.diamedeurogen.be/portals/1/770001.pdf )

15. De Jongh R, Vranken J, Kenis G, Bosmans E, Maes M, Stans G, De Ley M, Heylan R 1998 Clara cell protein: concentrations in cerebrospinal fluid, serum and amniotic fluid. Cytokine 10:441-444

16. Haslam PL, Baughman RP 1999 Report of ERS Task Force: guidelines for measurement of acellular components and standardization of BAL. Eur Respir J 14:245248

17. Doyle IR, Bersten AD, Nicholas TE 1997 Surfactant proteins-A and -B are elevated in plasma of patients with acute respiratory failure. Am J Respir Crit Care Med 156:1217-1229

18. Nomori H, Morinaga S, Kobayashi R, Torikata C 1994 Protein 1 and Clara cell $10-\mathrm{kDa}$ protein distribution in normal and neoplastic tissues with emphasis on the respiratory system. Virchows Arch 424:517-523

19. Peri A, Cordella-Miele E, Miele L, Mukherjee AB 1993 Tissue-specific expression of the gene coding for human Clara cell $10-\mathrm{kD}$ protein, a phospholipase A2inhibitory protein. J Clin Invest 92:2099-2109

20. Wang SZ, Rosenberger CL, Espindola TM, Barrett EG, Tesfaigzi Y, Bice DE, Harrod KS 2001 CCSP modulates airway dysfunction and host responses in an Ova-challenged mouse model. Am J Physiol Lung Cell Mol Physiol 281:L1303L1311

21. Bernard A, Thielemans N, Lauwerys R, Vandeleene B, Lambert AE 1993 The renal handling of protein 1 (Clara cell protein): effect of age, sex and renal dysfunction. Contrib Nephrol 101:66-70

22. Hermans C, Knoops B, Wiedig M, Arsalane K, Toubeau G, Falmagne P, Bernard A 1999 Clara cell protein as a marker of Clara cell damage and bronchoalveolar blood barrier permeability. Eur Respir J 13:1014-1021

23. Doyle IR, Hermans C, Bernard A, Nicholas TE, Bersten AD 1998 Clearance of Clara cell secretory protein $16(\mathrm{CC} 16)$ and surfactant proteins A and B from blood in acute respiratory failure. Am J Respir Crit Care Med 158:1528-1535

24. Kaneko K, Shimizu H, Arakawa H, Ogawa Y 2001 Pulmonary surfactant protein A in sera for assessing neonatal lung maturation. Early Hum Dev 62:11-21

25. Groneck P, Speer CP 1997 Pulmonary inflammation in the pathogenesis of bronchopulmonary dysplasia. Pediatr Pulmonol Suppl 16:29-30

26. Rojas MA, Gonzalez A, Bancalari E, Claure N, Poole C, Silva-Neto G 1995 Changing trends in the epidemiology and pathogenesis of neonatal chronic lung disease. J Pediatr 126:605-610

27. Chandra S, Davis JM, Drexler S, Kowalewska J, Chester D, Koo HC, Pollack S, Welch R, Pilon A, Levine CR 2003 Safety and efficacy of intratracheal recombinant human Clara cell protein in a newborn piglet model of acute lung injury. Pediatr Res 54:509-515

28. Pilon AL 2000 Rationale for the development of recombinant human CC10 as a therapeutic for inflammatory and fibrotic disease. Ann N Y Acad Sci 923:280-299

29. Griese M, Potz C, Dietrich P, Westerburg B 1996 Calcium, potassium, urea and total protein are not reliable dilutional markers of bronchoalveolar small volume-lavages in ventilated preterm human neonates. Eur J Med Res 1:565-570

30. Ward C, Fenwick J, Booth H, Walters EH 1997 Albumin is not suitable as a marker of bronchoalveolar lavage dilution in interstitial lung disease. Eur Respir J 10:20292033 